\title{
Ethical Dimensions of Shared Ethnicity, Language, and Immigration Experience
}

\section{Mabelle P. Victoria}

In this article I illustrate how some commonalities that I share with my participants - ethnic background, native language, and immigration experience-create unexpected ethical concerns. I explore how these commonalities facilitate the establishment of rapid intimacy, at the same time creating the temptations of overidentification and blurring the boundaries between researcher and participants. Drawing on three episodes from my ethnographic field work, I demonstrate how the mundane and taken-for-granted encounters with informants (used synonymously with participants) reveal the seeds of ethical dilemmas when put under the powerful and critical lens of reflexivity. Instead of viewing ethics as adherence to a set of codes, I explore reflexivity as ethical practice. Researchers continually make on-the-fly decisions in the field and take corresponding actions without the luxury of careful forethought. I argue that such decisions need to be unpacked after the event to examine if they carry ethical implications with them.

Dans cet article, je démontre dans quelle mesure des éléments que j'ai en commun avec mes participants - ethnicité, langue maternelle et expérience d'immigrant - créent des préoccupations inattendues de nature ethnique. J'explore à quel point ces éléments communs facilitent l'établissement rapide d'une certaine intimité, tout en évoquant la tentation d'une suridentification et en estompant les frontières entre le chercheur et les participants. Puisant dans trois épisodes de mon travail ethnographique sur le terrain, je démontre dans quelle mesure les rencontres banales et tenues pour acquis avec les répondants (ou participants) révèlent les germes de dilemmes éthiques quand on les examine sous l'optique puisant et critique de la réflexivité. Plutôt que d'interpréter l'éthique comme le respect d'un ensemble de codes, j'analyse la réflexivité comme pratique éthique. Sur le terrain, les chercheurs prennent constamment des décisions à la volée et entreprennent les actions correspondantes sans passer par une réflexion minutieuse. Je propose $q u$ 'on étudie attentivement ces décisions après coup pour déterminer s'il en découlent des conséquences sur le plan de la déontologie.

\section{Introduction}

The most important ethical considerations in qualitative research often involve three key concepts: ensuring voluntary and informed consent, maintaining confidentiality and participant anonymity, and protecting the respondents from harm (Fontman \& Fray, 2005). Cross-cultural contexts present re- 
searchers with particular challenges, usually involving language, differing roles and expectations, conflicting values and world views, power relations, and so forth (Liamputtong, 2010; Marshall \& Batten, 2003). Depending on the nature of the study and the target participants (e.g., children and other vulnerable groups, anonymous on-line respondents, etc.), researchers are expected to adhere to codes of ethics regardless of discipline. Indeed, as Stutchbury and Fox (2009) suggest, there seems to be no shortage of ethical codes for research that use human participants. For my study, I had to seek approval from my university's ethics committee and from the research site's ethics department before I was granted permission to collect data.

The ethical dilemmas that I discuss depart from viewing ethics as a set of codes or guidelines. This is not to undermine their utility, but to highlight that no code of ethics can substitute for the "individual's development of the capacity to make ethical decisions about the design and conduct of his or her own project" (Small, 2001, p. 405). My notion of ethical practice is intertwined with reflexivity, and this article is an attempt to make visible my "processes of uncertainty and reflection," which as Binns (2006) suggests, "cannot remain a matter of private contemplation, carried out behind the scenes of a neat and tidy research report" (p. 108). I use reflexivity here to refer to an "orientation to research and knowledge making which involves the researchers being critically self-aware of their own role in the research process (Swann, Deumert, Lillis, \& Mesthrie, 2004, p. 260). I broaden the notion by using reflexivity to include an ongoing critical self-awareness during and after any research-related activity.

\section{Researcher's Biography and Positionality}

I reject the idea of an "autonomous realm" that treats the investigator's biography, values, interests, and sociocultural location as if they could be extracted from the research process (Hammersley \& Atkinson, 2007). The questions we ask and how we go about seeking the answers are colored by who we are (Brew, 2001; Cameron, Frazer, Harvey, Rampton \& Richardson, 1992; Hammersley, 1992) or perhaps even by "what we want to be true" (Rowan, 1981, p. 136).

I am a border-crosser: I hold two passports, neither of which is of the country of my birth or the country of my present residence. I was born and raised in the Philippines, the eldest of six siblings of a lower-middle-class family. I am a non-native speaker of English; my mother tongue is Tagalog, one of the official languages of the Philippines alongside English. I came to Alberta in the late 1980s and worked for more than 15 years as an employment counselor for "disadvantaged" groups (immigrants, women reentering the work force, older workers). In 2000 I moved to Switzerland to join my Swiss husband. Currently I am pursuing a full-time doctorate in applied linguistics in the United Kingdom, where I live part of the time. 


\section{The Research Context}

My ethnographic research aims to explore the communication strategies that a group of Canadian immigrants from diverse cultural and linguistic backgrounds use to negotiate communication and build social relations. As part of the study, I conducted a three-week exploratory study in March 2009. This entailed the observation of diverse classes (10 ESL and four employment preparation classes for immigrants) in three separate locations: one a local college and the other two not-for-profit organizations. The data-collection phase took place between September and November 2009. Both phases were conducted in a western Canadian city. I used participant observation with audio-recordings of classroom talk as the principal method of data-collection, supplemented by unstructured interviews. The three examples I discuss were drawn from the exploratory study conducted in March.

\section{Insider/Outsider in Varying Degrees}

I share commonalities in varying degrees with my research participants. We are all immigrants to Canada; I do realize, however, that our experience of immigration is uniquely shaped by diverse variables (e.g., culture, knowledge of English/French, political conditions at time of immigration, etc.). It is probably safe to assume that I will have more in common with those who come from the Philippines than those who emigrated from other parts of the world. This brings up the notion of insider-outsider status, an important concept in qualitative research. It is not my intention to engage in the insideroutsider debate, as it has been extensively discussed elsewhere (Bridges, 2001; Corbin Dwyer \& Buckle, 2009; de Laine, 2000; Kusow, 2003, Merriam et al., 2001, Ryen, 2003, Sherif, 2001). Recognition is growing among scholars that "insider/outsider roles are products of the particular situation in which a given fieldwork takes place and not from the status characteristics per se of the researcher," (Kusow, p. 591); thus "like all social roles and statuses, are frequently situational, depending on the prevailing social, political, and cultural values of a given social context" (p. 593).

In the following section I discuss three episodes that I encountered in the field, which when viewed under the lens of critical reflexivity present areas of potential ethical friction. I unpack how my part-insider status by virtue of shared language, ethnicity, and immigration experience facilitates relationship-building, but presents dangers of over-rapport and over-identification. All the participants are attending employment preparation programs where they learn how to write letters of application, answer interview questions, adjust to the Canadian work place, and so forth.

\section{Episode 1. Tagalog or English: Torn Between Two Languages}

While observing classes in one of the nonprofit service-providers for immigrants, I met three Filipinos who were then attending a program for profes- 
sional engineers. They were friendly and referred to me as kabayan (Tagalog word for compatriot). This can be interpreted as an appeal to solidarity or a manifestation of what Merriam et al. (2001, p. 407) suggest as an "away from home" (p. 407) factor, a feeling of community between individuals from the same country when they find themselves in a foreign land. In one particular occasion, I was caught in an ethical dilemma when one of the Filipino participants, Mario, started to converse with me in Tagalog (all participants' names are pseudonyms). We were in the presence of other participants who did not know the language. I was tongue-tied, wondering if I should reply in English or Tagalog. Using Tagalog seemed to me the appropriate thing to do because Mario spoke to me in that language. If I answered in English, he might perceive it as arrogance and a rejection of solidarity. However, I felt that using Tagalog might be seen as rude and distancing by the other participants who were part of the group. In that split second, on the fly, I resorted to Taglish, a code-mixing of Tagalog and English, which is not an unusual way for Filipinos to express themselves in informal conversations. In this way I felt that I did not reject the shared ethnic identity that Mario was invoking and at the same time did not alienate the non-Tagalog-speaking immigrants who were part of the group.

\section{Episode 2. To Intervene or Not: Navigating Between Conflicting Roles}

The next episode took place on a bus journey to the research site. I ran into Teresa, a Filipina whom I had met twice in a class I was observing. We exchanged greetings and made small talk about the weather. I asked her what she thought about living in Canada. Switching from Taglish to full Tagalog, she said, "Hirap na hirap na ako talaga. Kailangan kong makahanap ng trabaho" (I am having a really tough time. I really need to find a job). I was surprised by the intimate nature of her self-disclosure. We had had no prior one-to-one contact apart from my having observed her class. During the 40minute bus ride, I learned that Teresa's husband had died a few months earlier. He was an alcoholic and was abusive to her. The very public bus contrasted with the private, intimate nature of our encounter. It was as if our common language had created a protective bubble that shielded us from the other passengers, who could hear but not understand what we were saying. I do not remember having said much during our talk; I listened to Teresa until it was time for us to get off the bus and go our separate ways. I asked her if she was all right, and she said, "Okey lang ako, okey lang " (I'm okay, I'm okay). Then she crossed the street to go to her class.

I was concerned for Teresa, so I had a chat with one of her employment counselors who happened to be a good friend and a former colleague. Without mentioning Teresa's name, I casually inquired how the participants were doing. From our talk, I gathered that the program staff were aware of Teresa's 
situation and that they had been providing her with the necessary support. I felt a sense of relief and decided not to do anything further at that point. When I came back for my main data-collection six months later, I found out that Teresa was doing very well; she was one of the first participants in her class to have been placed in a job with one of the city's largest financial institutions.

As I reflected on my encounter on the bus with Teresa, I wondered if anything I had said had encouraged her to reveal a painful part of her life. Was she harmed in any way? Did she feel distracted while attending class? Did our talk ruin her day? I cannot know for sure, but it is also possible that she felt relief and empowerment because I gave her undivided attention without judging her. As de Laine (2000) pointed out, I must "reconcile the self to com-

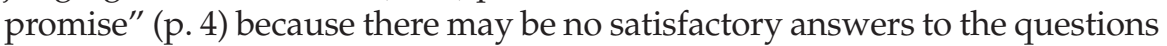
I have asked.

The point I wish to argue here is the need to "systematically produce doubts" (Reichertz, 2000) about one's behavior in the field in relation to participants. Ethics is, after all, to do with relational engagement (Binns, 2006), and trying to make sense of these relations is indispensable to ethical practice.

\section{Episode 3. Researcher or Employment Counselor: A Question of Identities}

Another ethical dilemma that I faced concerns a male immigrant from India, Surinder. I was writing my field notes in the lunch room when he approached me. He knew who I was because he was in one of the employment preparation classes that I observed. He introduced himself as a professionally trained mechanical engineer. He had come to Canada in 2004, but had had no success in finding suitable employment, which he attributed to racial discrimination. He said that he had sent out 180 résumés and application letters using his given name. Not a single employer had responded to his request for a job interview. He suspected that he was being screened out because of his ethnicsounding name. So he decided to change Surinder into "Sam," leaving the rest of the document untouched. Within a week of posting his "Sam" résumé and cover letter, he said that he had received two phone calls from employers requesting him to come for job interview. As he stood up to go back to his class, he left me with these words: "Decision is an act of choice; when you don't have a choice it's a compulsion. This program is helping, but what can we do to fight discrimination?"

While talking to Surinder, I had to resist the temptation to switch roles from that of researcher to that of employment counselor. As mentioned above, I had worked in the employment counseling field. Just like Surinder, I had difficulty in finding a suitable job when I was new to Canada. Meeting him reminded me of my own past struggles to fit into the Canadian work scene. Having been in his shoes, I felt like telling him "been there, done that, here's what you should do." 
Reflecting on the incident, a few questions come to mind. Had I tried to give Surinder job search suggestions, would he have appreciated it or construed it as an insult? How might someone from his cultural background react to an offer of help from a female and a relative stranger? Now I realize that those were the wrong questions to ask. They presuppose that Surinder needed my help, that he was somehow incapable of navigating the Canadian labor market; that I could assist him better than his employment counselors. I reframed my own questions: who do I think I am that I can just intervene in the lives of my participants and then go back to my student life in the UK to finish my thesis?

\section{Conclusion}

The three episodes discussed were unsolicited (Hammersley \& Atkinson, 2007); they occurred while I was not actively engaged in data-collection. In the first episode with Mario, it was a small talk in a hallway; with Teresa it was a chance encounter on a bus; with Sam I was busy doing something else when he started chatting to me in the lunch room. My encounters with these informants were not part of the interview process, nor do I treat them as interviews. The ethical implications of my actions could have gone unnoticed without the benefit of a reflexive lens and reflection. As Tulving (1991) points out, judgments about what is bad or what is good are seldom made in the present. It cannot be overstated, therefore, that reflexivity cannot be separated from ethical practice.

Although researchers often take on a variety of roles while doing field work, I would argue that the researcher's role has to take center stage. One can be friendly without being a friend, or be supportive without taking up the cudgel on behalf of the informants. The common ground that an insider researcher inhabits with the participants should be treated as an open window to see through, not as an open door to go into. As Hammersley and Atkinson (2007) put it, "one should never surrender oneself entirely to the setting or the moment." (p. 91). Refusing to surrender to the moment means the recognition that a fleeting denial of the researcher's role can carry serious ethical implications. Helping participants in need might be a noble thing to do, but this is not research. Social distance must be preserved in order to create space for analytic work to take place; "there must always remain some part held back" (p. 90).

In this article I demonstrate the possible ethical implications of conducting research with participants who share commonalities with the researcher. The real challenge in my study is not in teasing out the insider/outsider dilemma, but in seeking how to illuminate the space between (Corbin Dwyer \& Buckle, 2009) engagement and disengagement, involvement and detachment, closeness and distance. As I illustrate, ethical dilemmas can take up residence in the crevices, in the cracks between data-collection activities. I argue for the 
importance of reflexivity as a possible safeguard for minimizing over-rapport and over-identification. It is worth asking at this point: What practical benefit is there to reflect after the events, when harm, intentional or not, might have been done? Behind this question is the assumption that researchers are expected to have a clear idea of their values and beliefs before they enter the world of their participants; that they can always on the fly tell the ethical from the unethical without deliberation. The role of reflexivity as ethical practice is to disrupt these same values and beliefs in the light of new experiences, to create ambiguity and cause uncertainty, to expose researchers to their own pathologies. Indeed, it can be argued that an indispensable element of ethical practice is the liberation of the self from its set ways of thinking and behaving (Binns, 2006).

\section{The Author}

Mabelle Victoria is a full-time doctoral student at the Open University, UK. She has a master's degree in research (education) from the same university and an MA in TEFL from the University of Birmingham. Her current research focuses on exploring the communicative strategies and resources that people from varied cultural and linguistic backgrounds use to make intercultural communication work. She is interested in applying insights from linguistic ethnography and interactional sociolinguistics to the analysis of spoken interaction.

\section{References}

Binns, J. (2006). The possibilities of relational leading: Rethinking gender, power, reason and ethics in leadership discourse and practice. Unpublished doctoral dissertation, University of Western Australia.

Brew, A. (2001). Then nature of research: Inquiry in academic context. New York: Routledge Falmer.

Bridges, R. (2001). The ethics of outsider research. Journal of Philosophy of Education, 35, 371386.

Cameron, D., Frazer, E., Harvey, P., Rampton, M.B.H., \& Richardson, K. (1992). Researching language: Issues of power and method. London: Routledge.

Corbin Dwyer, S., \& Buckle, J. (2009). The space between: On being an insider-outsider in qualitative research. International Journal of Qualitative Methods, 8.

Fontman, H., \& Frey, J. (2005). The interview: From neutral stance to political involvement. In N. Denzin \& Y. Lincoln (Eds.), The Sage handbook of qualitative research (3rd ed., pp. 695727). London: Sage.

De Laine, M. (2000). Fieldwork, participation and practice: Ethics and dilemmas in qualitative research, London: Sage.

Hammersley, M. (1992). What's wrong with ethnography, London: Routledge.

Hammersley, M., \& Atkinson (2007). Ethnography principles in practice. New York: Routledge.

Kusow, A. (2003). Beyond indigenous authenticity: Reflections on the insider/outsider debate in immigration research. Symbolic Interaction, 26, 591-599.

Liamputtong, P. (2010). Performing qualitative cross-cultural research. Cambridge, UK: Cambridge University Press.

Marshall, A., \& Batten, S. (2003). Ethical issues in cross-cultural research. Available: http://www.educ.uvic.ca/Research/conferences/connections2003/10Marshall105.pdf

Merriam, S., Johnson-Bailey, J., Lee, M., Kee, Y., Ntseane, G., \& Muhamad, M. (2001). Power and positionality: Negotiating insider/outsider status within and across cultures. International Journal of Lifelong Education, 20, 405-416. 
Reichertz, J. (2000). Zur Gultigkeit von qualitativer Sozialforschung. Forum: A Qualitative Social Research Journal, 1, 2.

Rowan, J. (1981). On making sense. In P. Reason \& J. Rowan, J. (Eds.), Human inquiry: A sourcebook of new paradigm research. New York: Wiley.

Ryen, A. (2003). Cross-cultural interviewing. In J. Holstein \& J. Gumbrium (Eds.), Inside interviewing: New lenses, new concerns. Thousand Oaks, CA: Sage.

Small, R. (2001). Codes are not enough: What philosophy can contribute to the ethics of educational research. Journal of Philosophy of Education, 35(3), 387-405.

Sherif, B. (2001).The insider/outsider status. Qualitative Inquiry, 7, 436-447

Stutchbury, K., \& Fox, A. (2009). Ethics in educational research: Introducing a methodological tool for effective analysis. Cambridge Journal of Education, 4, 489-504.

Swann, J., Deumert, A., Lillis, T., \& Mesthrie, R. (2004). A dictionary of sociolinguistics. Edinburgh, UK: Edinburgh University Press.

Tulving, E. (1991). Memory research is not a zero-sum game. American Scientist, 46, 41-42. 